\title{
The Effects of an Arm Ergometer Training Programme on Wheelchair Subjects
}

\author{
A. W. Taylor, Ph.D., ${ }^{1}$ E. McDonell, M.Sc. ${ }^{1}$ and L. Brassard, M.Sc. ${ }^{2}$ \\ ${ }^{1}$ Faculty of Physical Education, University of Western Ontario, London, Ontario, \\ Canada, ${ }^{2}$ Université de Montréal, Montréal, Canada.
}

\section{Summary}

The purpose of the present investigation was to study the effects of an arm ergometer training programme on several physiological variables of recreational wheelchair subjects. Ten paraplegics (5 experimental, 5 control) were tested prior to and immediately after a 2 month exercise regimen at $80 \%$ of peak heart rate (30 min per day, 5 days per week, for 8 consecutive weeks at $50 \mathrm{rev} / \mathrm{min}$ ). The results demonstrated significant increases $(P<0.05)$ in $\dot{V} \mathrm{O}_{2} \max \left(1 \mathrm{~min}^{-1} \mathcal{E} \mathrm{ml} \mathrm{kg}^{-1} \mathrm{~min}^{-1}\right)$ and workload but only mild improvements in maximal heart rate and post exercise blood lactates. Body fat, vital capacity and forced expiratory volume did not change with training. Triceps lateralis fibre distribution and fast twitch (FT) fibre area were unaffected by the endurance training programme. However, slow twitch $(S T)$ fibre area increased $(P<0.05)$ with training. The results indicate that physiological variables of paraplegic subjects following an arm ergometer endurance training programme react similarly to changes previously observed in non-handicapped subjects. The values when compared with normals are low as a result of the relative inactivity of the subjects due to the lack of available exercise programmes for wheelchair people.

Key words: Paraplegic persons; Arm ergometer training programmes; Wheelchair persons; Muscle fibre types.

\section{Introduction}

Limited research has been carried out with the physically disabled and the effects of regular exercise or recreational play (Emes 1977; Glaser et al. 1980; Glaser et al. 1979; Hjeltnes 1977; Taylor et al. 1979; Zwiren and Bar-Or 1975).

Presently, sports and low organisation games are routinely used as physiotherapy for paraplegics but seldom are physiological variables monitored. It is

Correspondence to: A. W. Taylor.

Supported by grants from Fonds de Soutien 075-29-777 and Fitness Canada. 
therefore important to evaluate the physiological stress of these programmes and to compare the results with the effects of a training regimen. Since paraplegics cannot use their legs for locomotion, arm ergometry has been used to exercise test (Bar-Or and Zwiren 1975; Wicks et al. 1977-78) and train (Pollock et al. 1974; Glaser et al. 1979) these subjects. The purpose of the present investigation was to study the effects of an arm ergometer training programme on several cardiorespiratory and skeletal muscle variables.

\section{Methods and subjects}

Ten male subjects $16-55(X=30 \cdot 3)$ years of age participated in the study. All subjects played in a recreational basketball league which held two practices of two hours duration, plus at least one game, per week. The subjects were classified as category 3, 4 or 5 according to the system of the International Stoke-Mandeville Games Foundation and/or the medical classification of the Canadian Wheelchair Sports Association (Fig. 1). Three of the subjects were able to walk using crutches and/or long leg braces. All subjects were informed of the risks of the study and their right to terminate the project at will. Each expressed an understanding of these risks and signed an informed consent prior to any testing or exercise. Resting blood pressure was taken in the sitting position and the subjects were excluded from the study if the systolic pressure exceeded $150 \mathrm{mmHg}$. The protocol and procedures used for the study were approved by the Medical Ethics Committee of the Université de Montréal.

\section{Testing protocol}

Five of the subjects were randomly selected to follow the eight week training programme and the other 5 served as controls. All ten subjects continued to participate in the recreational basketball league. At the pre-training testing the subjects reported to the laboratory and the following anthropometric measurements were taken in the sitting position as previously described (McDonnell et al. 1981): weight, trunk height, arm girths, skinfolds (Allen et al. 1956), forced vital capacity (FVC) and forced expiratory volumes for one and three seconds $\left(\mathrm{FEV}_{1.0}, \mathrm{FEV}_{3.0}\right)$.

A resting blood sample was taken for lactate analysis and the subjects then commenced a maximal exercise test. Subjects sat on a wheelchair and the height of the seat was adjusted so that the axle connecting the pedal of the arm ergometer was at shoulder level. The test design for the arm cranking was a multistage progressive workload to a symptom-limited maximal performance. The initial load was standardised at $200 \mathrm{kgm} / \mathrm{min}$ and the load was sequentially increased every four minutes by $100 \mathrm{kgm} / \mathrm{min}$ until the subject could no longer keep pace with the cadence of $50 \mathrm{rev} / \mathrm{min}$. Expired air was collected during the last minute of each workload. The highest oxygen consumption was determined to represent the peak aerobic capacity during arm exercise. Heart rates were recorded on a Single Channel Electrocardiogram (Cambridge VS4) at the last 15 seconds of each workload using a standard three electrode attachment (CC5). The maximal heart rate was determined to be the highest heart rate during the maximal load. Five minutes after completing the exercise test a blood sample was collected from 


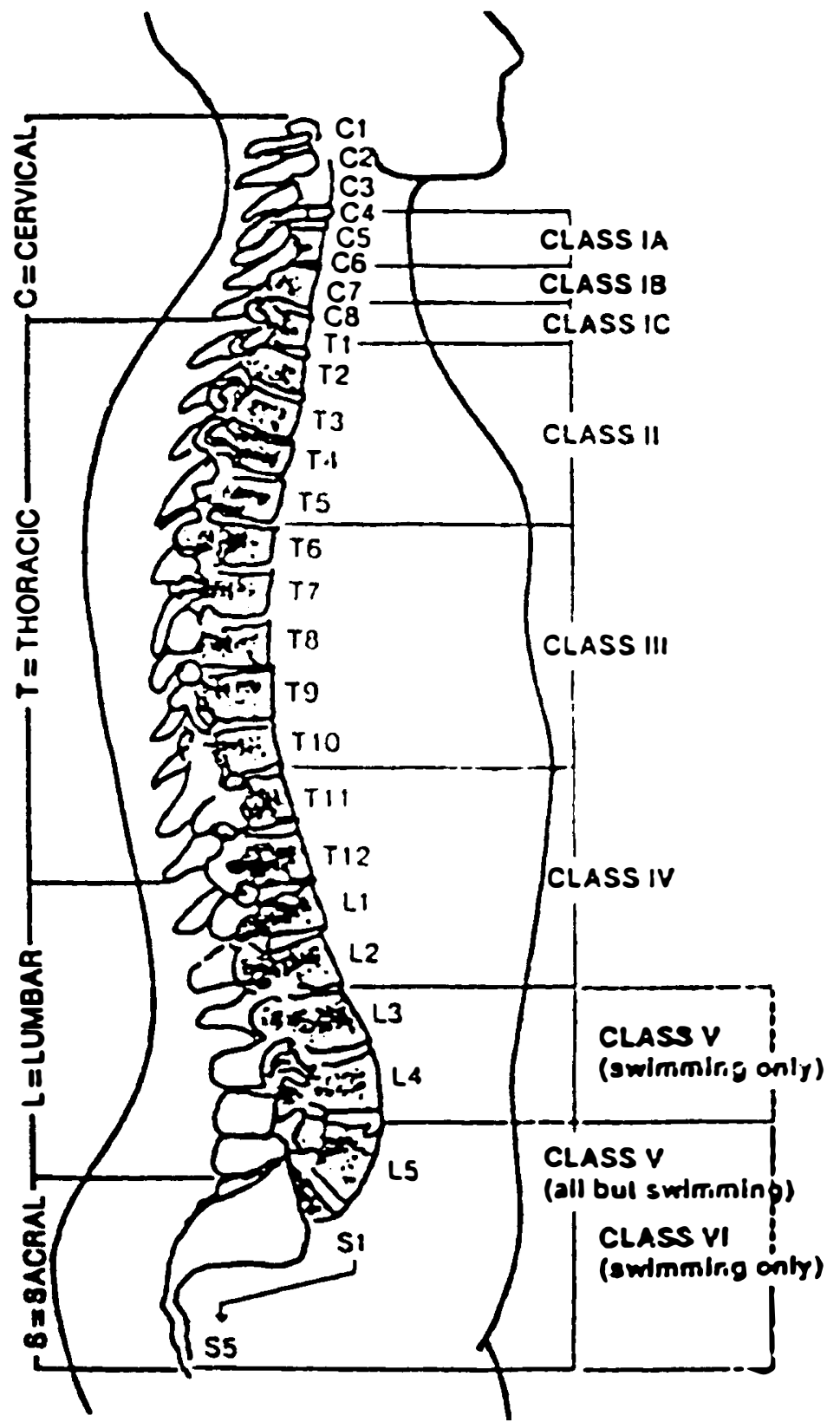

Figure 1. Spinal cord lesion area for classification for competition. International classification (Stoke-Mandeville Games).

a free-flowing digit puncture for maximal blood lactate determination. (Sigma Chemical Co. 1965).

Skeletal muscle biopsy samples were obtained from the lateral head of the triceps brachii according to the method described by Bergstrom (1962). Serial sections $(10 \mu)$ were classified as fast twitch (FT) and slow twitch (ST) using SDH 


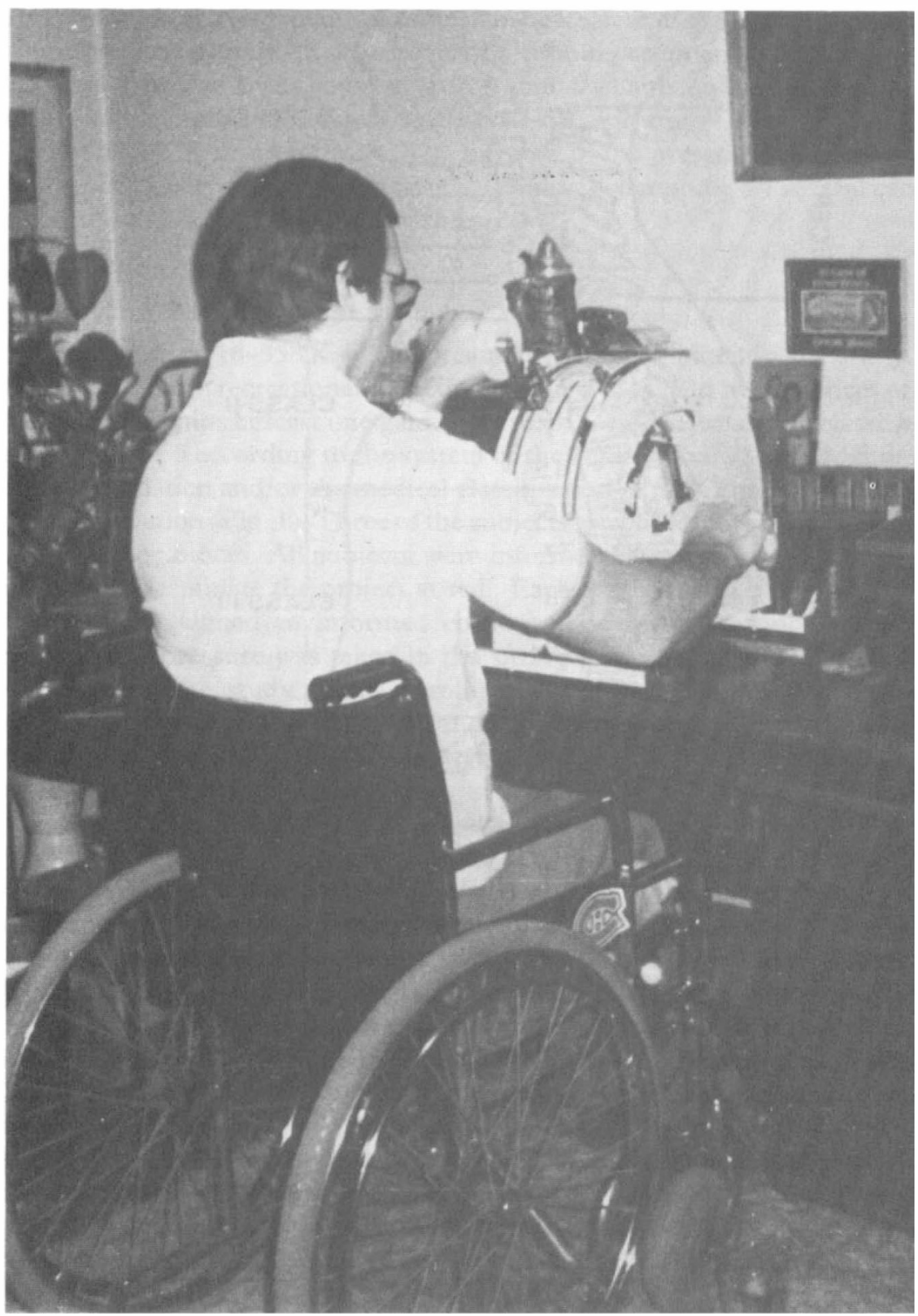

Figure 2. Paraplegic person training with use of the arm ergometer (Monark Rehab Trainer).

and myosin ATPase ( $\mathrm{pH} 10.4)$ staining techniques as described by Dubowitz and Brooke (1973) and Padykula and Herman (1955) as modified by Guth and Samaha (1970) respectively. Photographs of the slides were taken using a Polaroid MP4 Land Camera in connection with a Nikon microscope. Fibre cross-sectional area and distribution were determined from the SDH and ATPase micrographs, respectively, on a ZEISS Particle Analyser. 


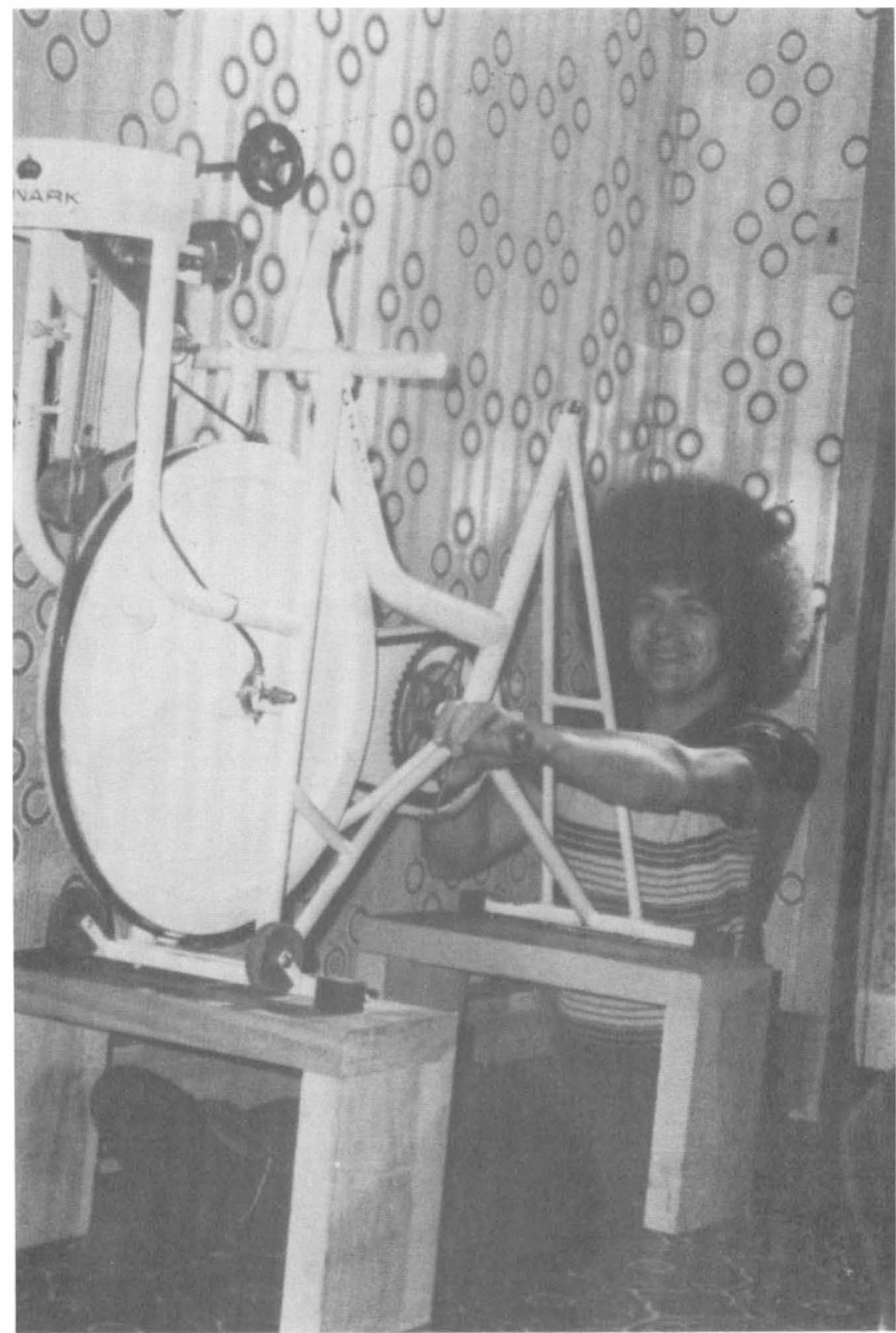

Figure 3. Paraplegic person training with use of the arm ergometer (Monark Ergocycle).

\section{Training program}

All subjects had normal upper body function and trained by arm pedalling at $50 \mathrm{rev} / \mathrm{min}$ for $30 \mathrm{minutes,} 5$ times weekly for eight consecutive weeks. Training was performed at the homes of the subjects using an ergometer, metronome and 
log sheet. Two arm ergometers (Monark Rehab Trainer) (Fig. 2) and three adapted conventional leg bicycle ergometers (Monark) were used for arm performance so that asynchronous propelling was possible. The adaptations were made by mounting the bicycle on two pieces of plywood so the subjects could pedal while sitting on the floor. The height was adjusted so the axis connecting the pedals would be at shoulder level (Fig. 3). The ergometer load was increased as the training progressed so that the heart rate was maintained at $80 \%$ of the highest heart rate achieved on the peak oxygen consumption test. All measurements were retaken at the end of the training programme following the abovedescribed protocol.

\section{Statistical procedures}

A t-test for the differences between means of paired observations was used for the experimental and control groups.

\section{Results}

The physical characteristics of the subjects are found in Table 1. The experimental group was significantly taller and heavier than the control group although no exercise or training effects were noted for these characteristics.

Table 1 Physical characteristics of subject population with arm ergometer training

\begin{tabular}{|c|c|c|c|c|c|c|c|c|c|c|}
\hline \multirow[b]{2}{*}{ Subject } & \multirow{2}{*}{$\begin{array}{l}\text { Age } \\
(\mathrm{yr})\end{array}$} & \multirow{2}{*}{$\begin{array}{l}\text { Height } \\
(\mathrm{cm})\end{array}$} & \multicolumn{2}{|c|}{$\begin{array}{c}\text { Weight } \\
(\mathbf{k g})\end{array}$} & \multicolumn{2}{|c|}{$\begin{array}{c}\text { Body Fat } \\
(\%)\end{array}$} & \multicolumn{2}{|c|}{$\begin{array}{c}\text { Arm } \\
\text { Circum- } \\
\text { ference }(\mathrm{cm})\end{array}$} & \multirow{2}{*}{$\begin{array}{c}\text { Time } \\
\text { Since injury } \\
(y r)\end{array}$} & \multirow[b]{2}{*}{ Classification } \\
\hline & & & pre & post & pre & post & pre & post & & \\
\hline \multicolumn{11}{|c|}{ Experimental Group } \\
\hline 1 & 32 & 60 & 89 & 86 & 16 & 13 & 34 & 39 & 14 & 3 \\
\hline 2 & 20 & 53 & 74 & 74 & 19 & 23 & 31 & 32 & 3 & 4 \\
\hline 3 & 26 & 53 & 86 & 82 & 15 & 17 & 31 & 34 & 6 & 3 \\
\hline 4 & 36 & 61 & 98 & 98 & 25 & 26 & 33 & 34 & 9 & 3 \\
\hline 5 & 22 & 61 & 62 & 60 & 14 & 14 & 25 & 29 & 4 & 3 \\
\hline Mean & 27 & 58 & 82 & 80 & 18 & 19 & 31 & 34 & - & - \\
\hline$\pm \mathrm{SD}$ & 3 & 4 & 13 & 13 & 4 & 5 & 5 & 3 & 一 & - \\
\hline \multicolumn{11}{|c|}{ Control group } \\
\hline 6 & 46 & 37 & 52 & 53 & 10 & 11 & 27 & 27 & 32 & 3 \\
\hline 7 & 23 & 52 & 58 & 53 & 10 & 10 & 32 & 30 & 16 & 5 \\
\hline 8 & 16 & 56 & 81 & 84 & 23 & 24 & 30 & 31 & 3 & 3 \\
\hline 9 & 55 & 42 & 62 & 61 & 13 & 13 & 32 & 30 & 1 & 4 \\
\hline 10 & 27 & 39 & 41 & 42 & 9 & 9 & 27 & 27 & 27 & 3 \\
\hline Mean & 33 & $45^{\star}$ & $59 \star$ & $59^{\star}$ & 13 & 14 & 29 & 29 & - & - \\
\hline$\pm \mathrm{SD}$ & 8 & 7 & 13 & 14 & 5 & 5 & 2 & 2 & - & - \\
\hline
\end{tabular}

* Significant differences between group means $(p<0.05)$.

Table 2 contains the cardiorespiratory measurements prior to and following the training regimen. A significant increase was noted for $\mathrm{VO}_{2} \max \left(1 \mathrm{~min}^{-1}, \mathrm{ml} \mathrm{kg}^{-1}\right.$ $\left.\min ^{-1}\right)$. Post exercise lactates increased significantly $(\mathrm{p}<0.05)$, however, no differences were noted between groups prior to and after training (Table 3 ). 
Table 2 Effects of arm ergometer training on resting and maximal cardio-respiratory characteristics of wheelchair subjects

\begin{tabular}{|c|c|c|c|c|c|c|c|c|c|c|c|}
\hline \multirow[b]{2}{*}{ Subject } & \multirow{2}{*}{$\begin{array}{c}\text { FVC } \\
(1 / \mathrm{min})\end{array}$} & \multirow{2}{*}{$\begin{array}{c}\mathrm{FEV}_{1 \cdot 0} \\
(\%)\end{array}$} & \multirow{2}{*}{$\begin{array}{c}\mathrm{FEV}_{\mathbf{3} \cdot 0} \\
(\%)\end{array}$} & \multicolumn{2}{|c|}{$\begin{array}{l}\text { Resting } \\
\text { H.R. } \\
\text { (b/min) }\end{array}$} & \multicolumn{2}{|c|}{$\begin{array}{c}\text { Maximal } \\
\text { H.R. } \\
\text { (b/min) }\end{array}$} & \multicolumn{2}{|c|}{$\begin{array}{c}\dot{\mathrm{VO}_{2}} \mathrm{Max} \\
(\mathrm{ml} / \mathrm{kg} / \mathrm{min})\end{array}$} & \multicolumn{2}{|c|}{$\begin{array}{c}\dot{\mathrm{VO}_{2} \mathrm{Max}} \\
(1 / \mathrm{min})\end{array}$} \\
\hline & & & & pre & post & pre & post & pre & post & pre & post \\
\hline \multicolumn{12}{|c|}{ Experimental group } \\
\hline 1 & $5 \cdot 71$ & 85 & 100 & 81 & 71 & 161 & 156 & $23 \cdot 8$ & $28 \cdot 0$ & $2 \cdot 1$ & $2 \cdot 4$ \\
\hline 2 & $5 \cdot 42$ & 82 & 100 & 74 & 77 & 147 & 142 & $22 \cdot 3$ & $26 \cdot 9$ & $1 \cdot 7$ & $2 \cdot 0$ \\
\hline 3 & $5 \cdot 32$ & 73 & 100 & 66 & 65 & 164 & 167 & $30 \cdot 9$ & $31 \cdot 7$ & $2 \cdot 8$ & $2 \cdot 6$ \\
\hline 4 & $4 \cdot 88$ & 77 & 97 & 82 & 78 & 142 & 150 & $18 \cdot 7$ & $21 \cdot 6$ & $1 \cdot 8$ & $2 \cdot 1$ \\
\hline 5 & 3.64 & 95 & 100 & 80 & 68 & 183 & 183 & $18 \cdot 3$ & $23 \cdot 2$ & $1 \cdot 7$ & $1 \cdot 6$ \\
\hline Mean & 4.99 & 82 & 99 & 77 & 72 & 159 & 160 & $22 \cdot 8$ & $26 \cdot 3^{\star}$ & 1.9 & $2 \cdot 1^{\star}$ \\
\hline$\pm \mathrm{SD}$ & .73 & 8 & 1 & 6 & 5 & 14 & 14 & $4 \cdot 6$ & 3.6 & 0.6 & 0.4 \\
\hline \multicolumn{12}{|c|}{ Control group } \\
\hline 6 & $3 \cdot 13$ & 72 & 95 & 68 & 81 & 153 & 150 & $22 \cdot 5$ & $27 \cdot 6$ & $1 \cdot 7$ & 1.5 \\
\hline 7 & $6 \cdot 80$ & 74 & 100 & 76 & 87 & 188 & 204 & $22 \cdot 8$ & $24 \cdot 5$ & $2 \cdot 5$ & $2 \cdot 4$ \\
\hline 8 & $6 \cdot 00$ & 79 & 98 & 99 & 94 & 165 & 167 & $18 \cdot 5$ & $20 \cdot 5$ & $1 \cdot 5$ & $1 \cdot 7$ \\
\hline 9 & 4.85 & 72 & 95 & 78 & 80 & 167 & 160 & $26 \cdot 7$ & $23 \cdot 0$ & $1 \cdot 7$ & 1.4 \\
\hline 10 & $2 \cdot 71$ & 93 & 100 & 77 & - & 163 & - & $22 \cdot 6$ & $21 \cdot 3$ & 0.9 & 0.9 \\
\hline Mean & $4 \cdot 70$ & 78 & 98 & 80 & $86^{\star \star}$ & 167 & 170 & $22 \cdot 6$ & $23 \cdot 4$ & $1 \cdot 7$ & $1 \cdot 6$ \\
\hline $\pm S D$ & 1.58 & 8 & 2 & 10 & 6 & 12 & 20 & $8 \cdot 5$ & 8.9 & 0.5 & 0.5 \\
\hline
\end{tabular}

* Significant increases with training $(P<0.05)$.

$\star \star$ Significant differences between groups $(P<0.05)$.

Table 3 Effects of arm ergometer training on resting and peak lactate concentrations of wheelchair subjects

\begin{tabular}{|c|c|c|c|c|}
\hline \multirow{2}{*}{ Experimental } & \multicolumn{2}{|c|}{$\begin{array}{c}\text { Rest } \\
\left(\mathrm{m} \mathrm{moll}^{-1}\right)\end{array}$} & \multicolumn{2}{|c|}{$\begin{array}{c}\text { Peak } \\
\left(\mathrm{m} \mathrm{moll}^{-1}\right)\end{array}$} \\
\hline & $2 \cdot 1$ & $1 \cdot 8$ & $7 \cdot 2$ & $8 \cdot 1$ \\
\hline & \pm 0.5 & \pm 0.9 & $\pm 2 \cdot 4$ & $\pm 1 \cdot 7$ \\
\hline \multirow[t]{2}{*}{ Control } & $1 \cdot 4$ & $2 \cdot 8$ & $7 \cdot 7$ & 10.9 \\
\hline & \pm 0.6 & \pm 1.4 & $\pm 3 \cdot 1$ & $\pm 1 \cdot 6$ \\
\hline
\end{tabular}

Values are means \pm S.D. for 5 subjects per group.

All values increased significantly with exercise $(P<0.05)$.

Table 4 Effects of arm ergometer training on triceps lateralis fibre distribution and area of wheelchair subjects

\begin{tabular}{|c|c|c|c|c|c|c|}
\hline \multirow[b]{2}{*}{ Group } & \multicolumn{2}{|c|}{$\begin{array}{c}\text { Distribution } \\
(\% \mathrm{ST})\end{array}$} & \multicolumn{2}{|c|}{$\begin{array}{c}\text { FT Area } \\
\left(\mu \mathrm{m}^{2} \times 10^{-3}\right)\end{array}$} & \multicolumn{2}{|c|}{$\begin{array}{c}\text { ST Area } \\
\left(\mu \mathrm{m}^{2} \times 10^{-3}\right)\end{array}$} \\
\hline & Pre & Post & Pre & Post & Pre & Post \\
\hline Experimental & $\begin{array}{c}48 \\
\pm 11\end{array}$ & $\begin{array}{l}56 \\
\pm 5\end{array}$ & $\begin{array}{r}9 \cdot 8 \\
\pm 2 \cdot 8\end{array}$ & $\begin{array}{r}10 \cdot 1 \\
\pm 4.0\end{array}$ & $\begin{array}{r}6.4 \\
\pm 2.3\end{array}$ & $\begin{aligned} & 8 \cdot 2_{\star \star}^{\star} \\
\pm & 2 \cdot 1\end{aligned}$ \\
\hline Control & $\begin{array}{l}53 \\
\pm 9\end{array}$ & $\begin{array}{l}56 \\
\pm \quad 7\end{array}$ & $\begin{array}{r}9 \cdot 3 \\
\pm 3 \cdot 1\end{array}$ & $\begin{array}{r}8.9 \\
\pm 3.3\end{array}$ & $\begin{array}{r}5.6 \\
\pm 1.7\end{array}$ & $\begin{array}{r}5 \cdot 8 \\
\pm 2 \cdot 1\end{array}$ \\
\hline
\end{tabular}

Values are means \pm SD for 5 subjects per group.

* Significantly increases with training $(P<0.05)$.

$\star \star$ Significantly different from control values $(P<0.05)$.

Skeletal muscle fibre distribution was normal and not affected by the training programme. The area of FT fibres did not change with training, however, significant increases in ST areas were recorded after endurance training $(P<0.05)$ (Table 4). 


\section{Discussion}

Zwiren and Bar-Or (1975) have noted differences in maximal oxygen consumption between trained and non-trained wheelchair subjects. In the present study, these expected increments were not accompanied with training bradycardia or reduced body fat components (Zwiren and Bar-Or 1975). These differences may have been related to the differences in classification of the subjects, or to the many inherent problems met in training paraplegic subjects such as inadequate training facilities, transportation to training sites, chair sores and ulcers, inadequate stabilisation in the chair and subject motivation (McDonell et al. 1981). The peak lactic acid concentrations were lower than values reported in the literature for arm cranking by non-handicapped subjects (Hjeltnes 1977; Bergh et al. 1976). These differences were likely due to the differences in testing protocol, subject populations of the level of training the subjects attained due to a probable lack of adherence $(75 \%$ of training regimen as estimated from the subjects' log sheets) to the programme (Glaser et al. 1980; McDonell et al. 1981).

It should be emphasised that, when working with the handicapped, in particular when dealing with subjects of different classification, group means may not be meaningful. For example, the ability of a class 2 , with limited if any ability to maintain unassisted balance in the wheelchair, to attain peak maximum that approaches the true maximum is most difficult. Since the availability of subjects of similar classification is sparse, we would recommend that future studies denote subject classification and that individual data be reported for methodologydependent variables.

Ekblom and Lundberg (1968) did not observe increases in $\mathrm{VO}_{2}$ max after a 6week conditioning programme but bradycardia was seen. This was probably due to their failure to stabilise the trunk during the testing (Astrand and Rodahl 1977). It has been demonstrated that wheelchair subjects of class 3 and 4 physiologically adapt to endurance training programmes (McDonell et al. 1981) similarly to normal subjects (Asmussen and Hemmingsen 1958). However, since the initial level of conditioning for the subjects is much less than that of sedentary normals, longitudinal studies are necessary to verify the effects of the lesion and the training programmes. It is possible to gain some insight into the effects of regular exercise by using a cross-sectional approach. We have previously studied skeletal muscle fibre distribution, area and enzyme activities from the triceps lateralis of class 3 and 4 elite wheelchair athletes (Taylor et al. 1979). Fibre distribution was found to be normal but enzyme activities were lower than normal and ST and FT areas were the largest yet reported in the literature. The fibre areas in the present study were slightly higher than for normal subjects and a training effect was found for the endurance type ST fibres. These data would suggest that the arm muscles used for wheelchair propulsion and crutch mobility adapt with increases in fibre size that are related to the force application of the training programme. This would suggest that arm musculature is more plastic than leg musculature due to the lesser levels of usage in our society and this should hold special implication for the trainability of these muscles.

Glaser et al. (1980) have recently noted that wheelchair propulsion is relatively inefficient when compared with arm cranking and have recommended that a wheelchair with arm crank propulsion be manufactured to produce less stress for 
a given workload. Presently we are training subjects with such a device (Unicycle 1980) which also includes either a 3 or 10 speed gear ratio similar to racing bicycles.

\section{Résumé}

Le but de la présente enquête est d'étudier les effets d'un programme d'entrainement ergométrique des bras sur plusieurs variables physiologiques chez des sujets immobilisés dans des fauteuils roulants. Dix cas paraplégiques ( 5 participants à l'expérience, 5 de contrôle) furent examinés avant et tout de suite après un régime d'exercice de deux mois à un taux de $80 \%$ du maximum du rythme cardiaque (30 min par jour, 5 jours par semaine, pendant 8 semaines consécutives à $50 \mathrm{rev} / \mathrm{min}$ ). Les résultats indiquent une augmentation remarquable $(P<0.05)$ du maximum V́O2 $\left(1 \mathrm{~min}^{-1} \&\right.$ $\mathrm{ml} \mathrm{kg}^{-1} \mathrm{~min}^{-1}$ ) et de la charge de travail mais seulement une légère amélioration du taux maximum du rythme cardiaque et des lactates du sang après l'exercice. Les graisses du corps, la capacité vitale et le volume expiratoire forcé sont restés les mêmes pendant l'entrainement. La distribution des fibres des triceps latéraux et les zones de fibres à contraction rapide (FT) sont restées inchangées par les efforts d'endurance du programme. Par contre les zones de fibres à contraction lente (ST) augmentent $(P<0.05)$ avec l'entraînement. Les résultats indiquent que les variantes physiologiques des sujets paraplégiques soumis au programme d'entraînement d'endurance ergométrique des bras correspondent à ceux observés antérieurement chez des sujets non-handicappés. Les valeurs comparées à la normale sont faibles, résultat de la relative inactivité des sujets due au manque de programmes d'activités disponibles pour les personnes immobilisées dans des fautevils roulants.

\section{Zusammenfassung}

Zweck dieser Untersuchung war es, die Auswirkungen eines Arm-Ergometer Trainingsprogramms auf mehrere physiologisch verschiedene Rollstuhl-Versuchspersonen in einem Erholungskontext zu betrachten. Zehn Querschnittsgelaehmte ( 5 Versuchs- und 5 Kontrollpersonen) wurden vor und direkt nach 2 Monaten systematischen Trainings-programms bei $80 \%$, Spitzenherzfrequenz (30 Minuten pro Tag, 5 Tage pro Woche, 8 aufeinanderfolgende Wochen bei 50 Umdrehungen pro Minute) untersucht. Die Ergebnisse zeigten eine bedeutende Zunahme $(\mathrm{P}<0,05)$ des $\mathrm{VO}_{2} \max$ $\left(1 \mathrm{~min}^{-1} \& \mathrm{ml} \mathrm{kg}^{-1} \mathrm{~min}^{-1}\right)$ und der Belastbarkeit, aber nur geringe Verbesserungen der maximalen Herzfrequenz und der Laktate im Blut nach den Uebungen. Koerperfett, vitale Leistungsfaehigkeit und gedraengtes Ausatmungsvolumen fett, vitale Leistungfaelingkeit und gedraengtes Ausatmungsvolumen aenderten sich nicht durch das Training. Die Faserverteilung des Triceps lateralis und der Faserbereich fuer schnelle Zuckungen (fast twich, FT) wurden von dem Ausdauertrainingsprogramm nicht beeinflusst. Der Faserbereich fuer langsame Zuckungen (slow twitch, ST) nahm jedoch mit dem Training zu $(P<0,05)$. Die Ergebnisse zeigen an, dass physiologisch verschiedene querschnittsgelaehmte Versuchspersonen, die an einem Ausdauer-trainingsprogramm mit ArmErgometer teilnehmen, mit aehnlichen Veraenderungen reagieren, wie man sie schon vorher an nicht behinderten Versuchspersonen beobachtet hatte. Die Werte sind verglichen mit Normalwerten niedrig, als Folge der relativen Inaktivitaet von Rollstruhl-Personen, fuer die es kaum spezielle Leibesuebungsprogramme gibt.

\section{References}

Allen TH, Peng MP, Chen KP, et al. 1956 Prediction of total adiposity from skinfolds and the curvilinear relationship between external and internal adiposity. Metabolism 5:346-352

ASMUSSEN E, HemmingSEN I 1958 Determination of maximum working capacity at different ages in work with the legs or with the arms. Scandinavian Journal of Clinical and Laboratory Investigation 10:67-71

Astrand PO, RodahL K 1971 Textbook of Work Physiology p. 372. McGraw-Hill Book Co., New York

BAR-OR O, ZWIREN LD 1975 Maximal oxygen consumption test during arm exercise-reliability and validity. Journal of Applied Physiology 38:424-426

BERGH U, KANSTRUP IL, EKBLOM B 1976 Maximal oxygen uptake during exercise with various combinations of arm and leg work. Journal of Applied Physiology 41:191-196

BERGSTROM J 1962 Muscle electrolytes in man. Scandinavian Journal of Clinical and Laboratory Investigations Supp. 68.

Dubowitz V, Brooke MH 1973 Muscle Biopsy: A Modern Approach, p. 30, Saunders, London. 
Ekblom B, LuNDBERg A 1968 Effects of physical training on adolescents with severe motor handicaps. Acta Paediatricia Scandinavia 57:17-23

Emes L 1977 Physical work capacity of wheelchair athletes. Res. Quart 48:209-212

Glaser RM, LAUBACH LL, SAWKA MN et al. 1979 Exercise stress, fitness evaluations and training of wheelchair users. In: Proceedings-International Conference on Lifestyle and Health, 1978: Optimal Health and Fitness for People with Physical Disabilities. A. S. Leon, G. F. Amendson (eds.) pp. 167-194, University of Minnesota Press, Minneapolis

GlASER RM, SAWKa MN, BRUNE MF, et al. 1980 Physiological responses to maximal effort wheelchair and arm crank ergometry. Journal of Applied Physiology 48:1060-1064

Glaser RM, SAWKa MN, LaUbach LL, et al. 1979 Metabolic and cardiopulmonary responses to wheelchair and bicycle ergometry. Journal of Applied Physiology 46:1066-1070

Guth L, Samaha FJ 1970 Procedure for the histochemical demonstration of actomyosin ATPase. Experimental Neurology 28:365-367

HJELTNES N 1977 Oxygen uptake and cardiac output in graded arm exercise in paraplegics with lower spinal lesions. Scandinavian Journal of Rehabilitation Medicine 9:107-113

MCDonnell E, BRASSARD L, MARTin P, et al. 1981 The effects of arm ergometer endurance training on physiological parameters of paraplegic wheelchair subjects. In: Recherches Actuelles en Activité Physique Adaptée, ed. K. Skrotzky, pp. 58-78, University of Montreal Press, Montreal

Padykula HA, Herman E 1955 The specificity of the histochemical method of adenosine triphosphatase. Journal of Histochemistry and Cytochemistry 3:170-195

Pollock ML, Miller MS, LinNerud AC, et al. 1974 Arm pedaling as an endurance training regimen for the disabled. Archives of Physical Medicine and Rehabilitation 51:418-424

Sigma Chemical Co. 1965 The determination of $\mathrm{L}(-)$ lactic acid in blood, plasma and other fluids at $340 \mathrm{mn}$. In: Technical Bulletin H825, St. Louis, Missouri

TAYLOR AW, MCDONEll E, ROYER D, et al. 1979 Skeletal muscle analysis of wheelchair athletes. Paraplegia 17:456-460

Unicycle. It Gets You Rolling 1980 Unicycle Inc., 2143, rue St. Patrick, Montreal.

WICKS JR, LyMBURNER K, DinsDale SM, et al. 1977-78 The use of multistage exercise testing with wheelchair ergometry and arm cranking in subjects with spinal cord lesions. Paraplegia 15:252-261

ZWIREN LP, BAR-OR O 1975 Response to exercise of paraplegics who differ in conditioning level. Medicine and Science in Sports and Exercise 7:94-98 